\author{
Robert Rajczyk (D) orcid.org/0000-0003-2848-4775 \\ Uniwersytet Śląski w Katowicach \\ robert.rajczyk@us.edu.pl
}

\title{
ZARZĄDZANIE KOMUNIKACJĄ KANDYDATÓW NA PREMIERA W SERWISIE FACEBOOK W WYBORACH PARLAMENTARNYCH W POLSCE W 2019 ROKU
}

\author{
Abstract \\ PRIME MINISTER CANDIDATES' COMMUNICATION MANAGEMENT ON \\ FACEBOOK DURING PARLIAMENTARY ELECTIONS CAMPAIGN 2019 IN POLAND
}

The article presents the results of a research, which was carried out in the last month of the parliamentary election campaign in 2019. In this research, the processes of communication conducted by candidates for deputies, Mateusz Morawiecki and Małgorzata Kidawa-Błońska, representing two rival parties ( $\mathrm{PiS}$ and $\mathrm{KO}$ ), were analysed - both candidates were simultaneously appointed as potential presidents of the Council of Ministers. The research was carried out using the qualitative method, taking into account the content of the profiles of both candidates on Facebook. Research results are part of the stream of analyzes, devoted to the importance of social media during election campaigns, as well as in the processes of political communication conducted by politicians.

Keywords: political communication, political campaign, Facebook, parliamentary elections

\section{Wprowadzenie}

Zdaniem Winfrieda Schulza (2014, s. 57-73) powstająca cyfrowa reprezentacja pozwala na budowanie relacji pomiędzy obywatelami a aktorami politycznymi dzięki interaktywności, pluralizmowi i kreacji nowych przestrzeni dyskursywnych. Rola mediów społecznościowych rośnie w kontekście ich zdolności do kreacji przestrzeni dyskursywnych (Shehata, Strömbäck, 2014, s. 93-113). Jednocześnie - jak pisze Gianluca Giansante (2015, s. 138-140) - korzystanie przez polityków zwłaszcza 
z serwisu Facebook, wskazuje na to, iż ich komunikacja jest prowadzona nieefektywnie i mało skutecznie, co wynika $\mathrm{z}$ ich lęku wobec oczekiwań komunikacyjnych otoczenia. Zdaniem Giansantego publikowane przez polityków posty o podobnej naturze, opisujące codzienne aktywności w sposób powierzchowny, nie są dla użytkowników interesujące, a jednocześnie infantylizują politykę, pozbawiając ją refleksji i analizy problemów. Takie działania komunikacyjne sprowadzają politykę do banalnych działań opartych na nieistotnym spektaklu. Giansante potwierdza, iż politycy nie rozumieją potencjału komunikacji sieciowej oraz istoty tworzenia takich treści przeznaczonych do zamieszczenia w sieci, które generowałyby wzrost uczestnictwa politycznego oraz wpływały na zwiększenie zainteresowania użytkowników. Wskazując na techniki kreacji informacji przeznaczonych dla serwisów społecznościowych Giansante (2015, s. 155) podkreśla znaczenie obrazów jako tych przekazów, które tworzą narracje, skuteczniej pobudzając interakcje niż inne formy przekazu, a także stanowią najczęściej udostępnianą treść. Jednocześnie zaznacza, iż potencjał komunikacyjny obrazów najczęściej jest przez polityków marnowany przez publikowanie powtarzalnych, nudnych i banalnych zdjęć, które kształtują wyobrażenie polityka jako osoby zaangażowanej w politykę (autor wskazuje na obrazy prezentujące polityków przemawiających, spotykających się z wyborcami w tych samych konwencjonalnych formach czy biorących udział w programach telewizyjnych). Problem profesjonalizacji sieciowego komunikowania politycznego podczas kampanii wyborczych nie jest więc tematem nowym (w Polsce analizy m.in.: Olczyk, 2014, 2015; Porębski, Żurek, 2017), zasługuje jednak na kontynuację analiz prowadzonych w kontekście profesjonalizacji aktów komunikacyjnych w sieci.

Artykuł ma charakter teoretyczno-empiryczny. Cel podjętych badań koncentruje się wokół analizy profesjonalizmu działań komunikacyjnych prowadzonych w przestrzeni serwisu Facebook przez osoby desygnowane na liderów dwóch prowadzących w sondażach w 2019 roku ugrupowań politycznych - Prawa i Sprawiedliwości oraz Koalicji Obywatelskiej (dalej odpowiednio: PiS oraz KO). W kontekście dalszych rozważań profesjonalizm komunikowania został zdefiniowany przede wszystkim w kontekście efektywnego wykorzystania narzędzia, jakim jest Facebook. Jako profesjonalne potraktowano prowadzenie procesu komunikowania z wykorzystaniem funkcjonalności serwisu oraz uwzględnieniem w kampanii wyborczej kandydata wytworzonej kultury serwisu Facebook. Przyjęto, że liderami obu wyżej wymienionych ugrupowań politycznych są kandydaci sugerowani na potencjalnych prezesów Rady Ministrów w wyniku wyborów parlamentarnych Mateusz Morawiecki (MM) oraz Małgorzata Kidawa-Błońska (MKB). Przyjęto, że komunikowanie liderów wykorzystujących użytkowość serwisu Facebook, świadczy o poziomie profesjonalizacji komunikowania prowadzonego z wykorzystaniem skonkretyzowanego kanału.

Wybór serwisu Facebook do analizy podyktowany był użytkowością platformy zapewniającej wysoki poziom trwałej interakcji i wysoką popularnością wśród 
użytkowników Internetu. Z raportu Digital 2020 wynika, że serwis Facebook w przypadku Polski oferuje możliwość dotarcia $\mathrm{z}$ treściami reklamowymi na poziomie 16 milionów użytkowników, z czego 53,4\% stanowią kobiety, a zasięg reklamowy dla całej populacji Polski powyżej 13. roku życia wynosi 49\% (Digital, 2020).

\section{Efektywna komunikacja jako element profesjonalizacji kampanii wyborczych}

Anthony Davis (2004, s. 19) uważa, iż skuteczny lider to zarazem skuteczny komunikator, który poprzez komunikację potrafi zbudować zaufanie do organizacji i przekazać jej wizję na przyszłość oraz jest zdolny do przewidzenia, zainicjowania i wdrożenia zmian. Podkreślanie znaczenia mediów cyfrowych jako bardziej wyrafinowanego narzędzia wyborów powoduje, że podczas kampanii wyborczych takie kanały są wykorzystywane po to, aby docierać do wyborców i generować historie, które następnie wykorzystują media głównego nurtu, tworząc w ten sposób reklamę polityczną wartą miliony (Neely, 2016). Jak podkreśla Aaron Smith (2014) liczba wyborców obserwujących kampanie online gwałtownie wzrosła w krótkim czasie. Kampanie cyfrowe umożliwiają wyborcom angażowanie się w proces wyborczy na nowe sposoby (Jenkins, 2007, s. 202-206; van Dijk, 2010; Semetko, 2010, s. 157-163; Grofman i in., 2014; Bessant, 2014, s. 120-135). Serwisy społecznościowe, tworząc określone społeczności wirtualne, umożliwiają wykraczanie poza ustalane hierarchie, co powoduje, że elity medialne i polityczne tracą możliwość kontroli nad komunikowaniem podczas kampanii wyborczej. Powstające interakcje online dają możliwości zaangażowania obu stron w procesy komunikowania podczas kampanii wyborczych - kandydatom ułatwiają dotarcie z przekazem wprost do wyborców, a wyborcom aktywny udział w kampanii poprzez możliwość wyrażania opinii, tworzenie własnych treści, rozpowszechnianie informacji z wykorzystaniem własnych zasięgów sieciowych. Jak wskazują Shoko Kiyohara, Kazuhiro Maeshima i Diana Owen (2018, s. 138-140) istnieją trzy typy zaangażowania wyborców w procesy komunikowania sieciowego podczas kampanii wyborczej. Poziom niski polega na monitorowaniu, wyszukiwaniu oraz konsumpcji informacji. Średni natomiast to wyrażanie poparcia lub sprzeciwu wobec kandydatów oraz wchodzenie $w$ interakcje $z$ treściami, jakie politycy oraz inne podmioty umieszczają w sieci. Zaangażowanie na poziomie średnim oznacza także korzystanie z kilku kanałów komunikowania, co pozwala na zróżnicowanie sposobów i narzędzi partycypacji w dyskursie. Wysoki poziom zaangażowania z kolei zasadza się na aktywnych formach komunikowania, takich jak tworzenie przekazów (filmów, memów), relacjonowanie wydarzeń w sieci, zachęcanie innych do udziału w wyborach.

Coraz częściej podkreśla się znaczenie wizerunku, jako podstawowego czynnika personalizacji kampanii wyborczej, wskazując, iż to wizerunek staje się jednym 
z czynników zwycięstwa wyborczego. Kształtowany za pomocą komunikacji w sieci obraz kandydata powoduje, że istotne stają się nie tylko doświadczenia i wiedza kandydata, ale także jego zdolność autoprezentacji. Ważnym czynnikiem wpływającym na sposób postrzegania kandydata jest też płeć, która w przypadku kandydatek obejmuje więcej czynników branych pod uwagę w procesie kreacji wizerunku niż tych odnoszących się do mężczyzn. Chodzi zwłaszcza o elementy komunikowania pozawerbalnego, obejmujące ubiór, zdolność do wyrażania emocji oraz przekaz niewerbalny dotyczący zdolności przywódczych. W wyniku dyskursu powstają zaś projekty narracyjne uwzględniające dialektykę między stałością a zmianą. Podejście narracyjne ukazuje, jak wartości i cele osoby zmieniają się w czasie i pod wpływem wydarzeń, ale nadal odnoszą się do tej samej osoby (Umbach, Humphrey, 2018, s. 231-232). Personalizacja polityki prowadzi do walki konkurencyjnej pomiędzy politykami, a nie ideami czy ideologiami, jakie reprezentują. Zdaniem badaczy merytoryczna dyskusja traci powoli na znaczeniu w przestrzeni dyskursu, będąc wypieraną przez walkę konkurencyjną pomiędzy politykami - problemy są upraszczane, za to konflikty przeceniane (Iyengar, McGrady, 2007, s. 69-70; Umbach, Humphrey, 2018, s. 214-215).

Personalizacja polityki oddziałuje również na polaryzację postaw i zachowań jednostek. Jak uważa Lilliana Mason (2018, s. 886), identyfikacja społeczna może przybrać dwojaki charakter - identyfikacji inkluzywnej, w której jednostka staje się częścią grupy, lub ekskluzywnej, w wyniku której odstaje od grupy. Funkcją identyfikacji grupowej staje się nazewnictwo. Przykładowo określanie kandydatów mianem „liberałowie” albo „konserwatyści” wyznacza spolaryzowaną identyfikację na poziomie symbolicznym i zarazem ideologicznym, a także zawiera wymiar afektywny, związany z istniejącymi animozjami pomiędzy wymienionymi grupami. Polaryzacja afektywna rośnie wraz ze wzrostem polaryzacji ideologicznej, identyfikowanej głównie symbolicznie (Iyengar, Sood, Lelkes, 2012; Iyengar, Westwood, 2015). Duże znaczenie w tym kontekście przypisuje się więc osądom wynikającym $\mathrm{z}$ relacji zachodzącej pomiędzy emocjami jednostki (strachem i gniewem lub entuzjazmem) a podmiotem wewnątrz- lub zewnątrzpartyjnym (liderem). Jednostka odczuwa wobec lidera ugrupowania zewnętrznego (opozycyjnego wobec ugrupowania, jakie sama popiera) strach i wówczas reaguje gniewem, z kolei wobec lidera własnego ugrupowania przejawia entuzjazm. Zdaniem Cengiza Erisena (2018, s. 166-172) obawy mają związek z sympatiami, co oznacza, że wyborcy raczej obawiają się kandydatów, których nie lubią, niż nie czują sympatii do tych kandydatów, którzy wzbudzają w nich lęk. Diana C. Mutz (2010, s. 141-142) podkreśla, że już w latach 60 . XX wieku identyfikacja wyborcy z konkretną partią wywoływała stronniczość prowadzącą do selektywnego konsumowania informacji, a co za tym idzie - powodowała selektywne interpretowanie informacji, tak by nie naruszały one istniejących poglądów i sympatii jednostki. Oznacza to, zdaniem Mutz, iż jednostki wybierają takie źródła informacji, które pozwalają im na potwierdzanie posiadanych przekonań, przetwarzanych i interpretowanych także zgodnie $\mathrm{z}$ ich 
preferencjami. Tym samym, komunikacja sieciowa poprzez tworzenie wirtualnych społeczności - zwykle kreowanych na zasadzie polaryzacji - skupia osoby podzielające wspólne wartości, co wpływa na tendencyjne przetwarzanie treści, zgodnie $\mathrm{z}$ afektywnym modelem sympatii albo antypatii.

Profesjonalizacja kampanii wyborczych coraz częściej polega na zarządzaniu komunikacją w sieci w taki sposób, aby zaangażować samych użytkowników do samodzielnego tworzenia i upowszechniania treści kosztem tradycyjnych metod realizacji kampanii polegającej na spotkaniu z kandydatem oraz weryfikowaniu jego programu wyborczego (Sheingate, 2016, s. 151-153). Prowadzi to do sytuacji, w której dyskurs podczas kampanii wyborczych wychodzi poza niedopuszczalne wcześniej normy społeczne, przede wszystkim w warstwie używanego języka. Kandydaci nie przebierają w słowach, atakując przeciwników, podobnie jak obywatele, którzy za sprawą obalania hierarchii politycznych i medialnych oraz odgrywania aktywnej roli w kształtowaniu dialogu w kampanii i dzięki celowej aktywizacji stali się kreatorami, a nie tylko odbiorcami treści wyborczych (Anderson i in., 2014, s. 374; Sun, 2018, s. 303-321).

Reasumując powyższe rozważania, można przyjąć, iż komunikacja w sieci jest kolejnym miejscem wyrażania spolaryzowanych opinii wyborców, skoncentrowanych w tej przestrzeni, która pozwala na swobodne wyrażanie treści zgodnych z preferencjami wyborczymi kandydatów. Oznacza to, że wokół profilu lidera w mediach społecznościowych skupiają się jego zwolennicy oraz obserwatorzy, którzy są skłonni podzielać wyrażane opinie. Komunikacja kandydatów jest wspierana poprzez umiejętne angażowanie użytkowników proces tworzenia i rozprzestrzeniania informacji wpływających na wizerunek polityka oraz przez prezentowanie go w pożądany sposób oraz popularyzowanie w sieci.

\section{Różnice płciowe w zarządzaniu komunikacją kandydatów}

Agresja przypisywana w polityce mężczyznom służy wizerunkowo (na zasadzie przeciwieństwa) kobietom politykom, które są częściej wiązane z uczciwością w polityce oraz traktowane jako nieuwikłane w "grę o władzę". Co więcej, kobiety są postrzegane jako bardziej emocjonalne i empatyczne, co w dobie wykorzystywania prywatności polityków staje się niewątpliwą zaletą w kontekście komunikowania wizerunku przywódcy. Konstruowanie różnic płciowych, mających swoje źródła w kulturze lub ideologii, ma związek ze sposobem myślenia określającym ludzkie zachowania. Jednocześnie bycie osobą określonej płci rodzi prawdopodobne i zauważalne konsekwencje w procesie zdobywania oraz utrzymania władzy i przywództwa (Keohane, 2010, s. 128). Jak wskazują Deborah L. Rhodes i Barbara Kellerman (2007, s. 16-17) kobiety sytuowane w roli przywódcy częściej zorientowane są na uczestnictwo i komunikację interpersonalną, kierują się empatią i przejawiają cechy wspierające. Jednocześnie kobiety wykazują potrzebę 
dzielenia się władzą oraz podejmowania decyzji na zasadzie konsensusu. Donatella Campus (2013, s. 31-35) twierdzi, iż styl przywództwa kobiet można określić mianem przywództwa interaktywnego, w którym wizerunek kobiet jest rezultatem interakcji z podwładnymi, uczestnictwa, dzielenia się informacjami i podnoszenia samooceny innych ludzi w wyniku pracy zespołowej. W przypadku mężczyzn styl przywództwa przybiera częściej charakter autokratyczny, polegający na kontroli i wyeksponowaniu mężczyzny jako lidera. Istnieją koncepcje zarówno wskazujące, iż różnice w sposobie przywództwa pomiędzy kobietami i mężczyznami zmniejszają się wprost proporcjonalnie ze wzrostem znaczenia kobiety w organizacji, jak i podkreślające zupełny brak różnic $\mathrm{w}$ typie przywództwa pomiędzy przedstawicielami obu płci. Pierwsza ze wskazanych teorii podkreśla, iż kobiety na wysokich szczeblach przypominają zachowaniem swoich męskich odpowiedników, preferując konkurencyjność i kontrolę. Druga z koncepcji odrzuca istnienie różnic płciowych, wskazując iż osoby obu płci zachowują się podobnie i wykazują zbliżoną zdolność do współpracy, a wyznacznikiem stylu przywództwa jest grupa społeczna, której jednostka przewodzi (Collins, Singh, 2006, s. 15).

\section{Metodologia badań}

Podjęty problem badawczy polega na ustaleniu, w jakim stopniu kandydaci na premiera dwóch największych partii politycznych w Polsce podczas kampanii wyborczej w 2019 roku używali serwisu Facebook, wykorzystując jego funkcjonalności. Jako problem badawczy przyjęto również ustalenie, czy różnice w płci obu kandydatów znalazły swoje odzwierciedlenie w aktach komunikacyjnych.

Badania wizerunku liderów typowanych do objęcia urzędu Prezesa Rady Ministrów po wyborach do parlamentu w 2019 roku zostały zrealizowane metodą ilościową i poprzez analizę treści opublikowanych w serwisie społecznościowym Facebook. Badaniem objęto ostatni miesiąc trwania kampanii wyborczej (12.09.2019-11.10.2019). Poprzez pomiar ilościowy zbadano liczbę opublikowanych postów na profilach każdego z kandydatów podczas kampanii wyborczej (każdy post stanowił jedną jednostkę kategoryzacyjną). Analiza ich treści pozwoliła na wyodrębnienie następujących kategorii badawczych:

a) kategorie tematyczne: polityka, gospodarka, technologie, kultura i historia, sprawy społeczne, zdrowie, polityka międzynarodowa oraz relacje Polski z UE, polityka migracyjna;

b) kategorie udostępnianej aktywności: eventy i spoty wyborcze, autoprezentacja kandydata (np. konferencje prasowe kandydata), relacje ze spotkań z wyborcami, aktywność medialna kandydata (udział w programach lub audycjach emitowanych w mediach tradycyjnych, $\mathrm{z}$ których relacje zamieszczono na profilu kandydata). 
Kluczem kategoryzacyjnym zastosowanym w dokonanej analizie były: dla kategorii tematycznych - analiza treści wypowiedzi, a dla kategorii aktywności - rodzaj podjętej aktywności, bez względu na treść towarzyszących jej wypowiedzi. Każdy post był przypisywany wyłącznie do jednej grupy. Celem przeprowadzonej analizy treści było dokonanie oceny zarządzania prowadzoną komunikacją z uwzględnieniem takich elementów, jak wykorzystywanie funkcjonalności serwisu, emocjonalność i personalizacja przekazu. Każdemu ze wskazanych elementów przypisano określone cechy będące przedmiotem badania treści oraz ilustrowanych zdjęciami/ relacjami filmowymi. Do każdej z wymienionych kategorii przypisano pytania, na które poszukiwano odpowiedzi w przeprowadzonej analizie jakościowej.

1. Wykorzystywanie funkcjonalności serwisu: czy kandydat stosował narzędzia komunikowania przypisane social mediom - znaczniki \#, oznaczanie miejsca aktywności, wykorzystywanie oznaczeń emocji dostępnych w serwisie Facebook; interakcje z użytkownikami - prowadzenie przez kandydata sieciowego dialogu $\mathrm{z}$ jego fanami.

2. Emocjonalność: jakimi osobami uznawanymi za autorytety kandydat otaczał się w prowadzonej kampanii; jak kandydat prezentował swoją aktywność w spotkaniach $\mathrm{z}$ wyborcami; jak budował interakcje podczas spotkań wyborczych; czy kandydat wykazywał się poczuciem humoru, dystansem wobec siebie w publikowanych treściach; jak kandydat komunikował istotne dla siebie wartości; czy kandydat w swojej sieciowej aktywności odwoływał się do programu kontrkandydata.

3. Personalizacja: jak prowadzono konto kandydata (bezosobowo, w pierwszej osobie liczby pojedynczej czy inaczej); czy kandydat pozycjonował się, zwracając uwagę na ugrupowanie polityczne, które reprezentował; czy w przekazach kandydata była obecna jego rodzina; czy w okresie badania kandydat traktował fanpage jako miejsce przekazu informacji o charakterze osobistym; w jakich miejscowościach kandydat spotykał się z wyborcami; jaki obraz kandydata wynikał z treści dominujących w tematyce prowadzonej komunikacji w serwisie Facebook; jak kandydat był prezentowany w kontekście interakcji z wyborcami podczas spotkań wyborczych (w otoczeniu tłumu, czy wybranych osób); jak kandydat budował przekazy na temat programu wyborczego partii.

W badaniach przyjęto następujące hipotezy:

H1. Kandydaci wykorzystują dostępne funkcjonalności, budując przekazy przeznaczone dla spolaryzowanej grupy użytkowników.

H2. Profile liderów prowadzone podczas kampanii wyborczej, nie mają charakteru spersonalizowanego, stanowią zaś źródło przekazów partyjnych ugrupowania, które lider reprezentuje.

H3. Komunikowanie odwołuje się do różnic ze względu na płeć nadawcy.

Badanie miało charakter eksploracyjny. W celu weryfikacji hipotez przyjęto następujące pytania badawcze: 
1. Czy przekaz treści udostępnianych przez kandydatów w serwisie Facebook miał charakter profesjonalny ( $\mathrm{z}$ uwzględnieniem elementów, które wyszczególniono powyżej)?

2. Czy sposób komunikowania się był spersonalizowany, czy za pośrednictwem profilu kandydata przekazywano również informacje partyjne?

3. Czy komunikowanie liderów było prowadzone z uwzględnieniem zróżnicowania ze względu na płeć nadawcy? Jeśli tak, to w jaki sposób te różnice ujawniły się w procesie komunikowania?

\section{Zawartość profili kandydatów oraz poziom upartyjnienia treści}

W wyniku dokonanych pomiarów liczbowych aktywności kandydatów wskazano, iż w badanym okresie kandydatka KO opublikowała 109 postów, a jej kontrkandydat 136. Tabela 1 obrazuje zasięgi wygenerowane przez każdego z kandydatów do liczby opublikowanych postów. Zasięgi podane w tabeli nie uwzględniają zróżnicowania na zasięgi organiczne i wspomagane.

Tabela 1. Zasięgi wygenerowane przez profile każdego z kandydatów w okresie 12.09.2019-11.10.2019

\begin{tabular}{|l|l|l|l|}
\hline PROFIL/LICZBA & POLUBIENIA & KOMENTARZE & UDOSTĘPNIENIA \\
\hline MKB & 153597 & 15923 & 18713 \\
\hline MM & 96757 & 14238 & 12402 \\
\hline
\end{tabular}

Źródło: opracowanie własne na podstawie danych z serwisu Facebook.

Z tabeli wynika, iż liczba komentarzy i udostępnień w przypadku każdego $\mathrm{z}$ kandydatów była zbliżona, różnice wynikały z liczby osób lubiących posty każdego $\mathrm{z}$ kandydatów. Zestawiając te dane $\mathrm{z}$ dynamiką przyrostu fanów każdego $\mathrm{z}$ kandydatów w badanym okresie (na dzień 12 września liczba fanów dla obu kandydatów była zbliżona i wynosiła około 22 tys. osób lubiących i obserwujących, na koniec okresu badawczego w przypadku M. Kidawy-Błońskiej liczba ta wzrosła nieznacznie i wynosiła niespełna 30 tys. fanów i obserwujących, w przypadku M. Morawieckiego zaś wzrosła do około 55 tys. fanów i obserwujących), można stwierdzić, iż to kandydat PiS był skuteczniejszy w pozyskiwaniu zainteresowania użytkowników w sieci. W badanym okresie każdy z kandydatów opublikował na swoim profilu 28 filmów, które wygenerowały różne zasięgi: w przypadku M. Kidawy-Błońskiej było to niemal 600 tys. wyświetleń, a w przypadku M. Morawieckiego - niespełna 480 tys. wyświetleń. To wskazuje, że pomimo większego zaangażowania kandydata 
PiS na premiera w prowadzenie komunikacji w serwisie Facebook (liczba postów ${ }^{1}$, wzrost zainteresowania samym profilem kandydata), treści umieszczane przez M. Kidawę Błońską cieszyły się większym zainteresowaniem, generując tym samym większe zasięgi sieciowe.

Przeanalizowanie zawartości udostępnianej na analizowanych profilach (tabela 2) oraz aktywności podejmowanej w ostatnim miesiącu (tabela 3) pozwala zauważyć podobieństwa w prowadzeniu kampanii wyborczej przez każdego z kandydatów.

Tabela 2. Tematyka postów kandydatów w okresie 12.09.2019-11.10.2019

\begin{tabular}{|c|c|c|c|c|c|c|c|}
\hline & $\begin{array}{l}\mathbb{5} \\
0 \\
0 \\
0 \\
0 \\
0 \\
0\end{array}$ & 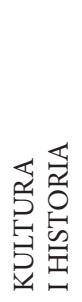 & 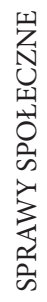 & 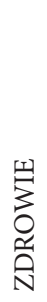 & 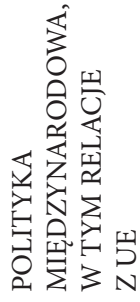 &  & 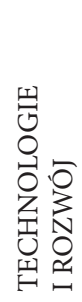 \\
\hline MKB & 3 & 3 & 6 & 6 & 0 & 0 & 0 \\
\hline MM & 12 & 2 & 9 & 2 & 5 & 0 & 3 \\
\hline
\end{tabular}

Źródło: opracowanie własne na podstawie danych z serwisu Facebook.

Tabela 3. Aktywność wyborcza kandydatów w okresie 12.09.2019-11.10.2019

\begin{tabular}{|c|c|c|c|c|c|}
\hline & 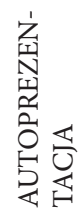 & 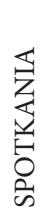 & 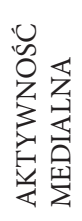 & 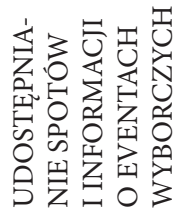 & 㞱 \\
\hline MKB & 28 & 28 & 1 & 22 & 8 \\
\hline MM & 17 & 69 & 2 & 8 & 6 \\
\hline
\end{tabular}

Źródło: opracowanie własne na podstawie danych z serwisu Facebook.

Problematyka postów była zbliżona. W przypadku M. Morawieckiego dominowały zagadnienia gospodarcze oraz sprawy społeczne (tematyka międzynarodowa

1 Należy dodać, iż od 30 września do 7 października Mateusz Morawiecki nie prowadził komunikacji w serwisie Facebook w związku ze śmiercią ojca - Kornela Morawieckiego. 
oraz relacje Polski z UE pojawiły się wyłącznie w postach relacjonujących wykonywanie przez kandydata funkcji premiera podczas spotkań międzynarodowych). Z kolei u M. Kidawy-Błońskiej dominowała tematyka społeczna oraz ochrony zdrowia jako przedmiot postów. Tematyką zupełnie pomijaną przez obu kandydatów był problem migracji, podobnie rzecz się miała w odniesieniu do kultury. W przypadku profilu M. Kidawy-Błońskiej nie pojawiły się posty dotyczące problematyki technologii i rozwoju. Aktywności prezentowane przez oboje kandydatów były zróżnicowane co do ich intensywności. Profil M. Kidawy-Błońskiej był częściej wykorzystywany jako miejsce publikowania treści partyjnych (spoty wyborcze oraz relacje $\mathrm{z}$ konwencji wyborczych).

Publikując posty, kandydaci współpracowali z osobami znanymi i rozpoznawalnymi publicznie, korzystając $\mathrm{z}$ transferu ich wizerunku. Morawiecki zamieścił posty relacjonujące spotkanie $\mathrm{z}$ udziałem prof. Mariana Zembali (M. Morawiecki wziął w nim udział jako premier) oraz z udziałem polskich siatkarzy, którym premier kibicował i wsparł ich wyjazd udostępniając rządowy samolot. M. Kidawa-Błońska z kolei prezentowała się z osobami, które jednoznacznie kojarzyły się politycznie jako opozycja wobec rządzących: z Lechem Wałęsą, Donaldem Tuskiem, posłanką do Parlamentu Europejskiego Magdaleną Adamowicz, prezydentami Sopotu i Gdańska oraz ówczesnym liderem PO Grzegorzem Schetyną. Tym samym zawartość profilu M. Kidawy-Błońskiej była bardziej upolityczniona i kojarzona z ugrupowaniem politycznym, które reprezentowała, niż zawartość profilu kontrkandydata. W prowadzonej w serwisie Facebook komunikacji każdy z kandydatów odwoływał się do programu konkurencyjnej partii politycznej, krytykując pomysły rywali oraz przeciwstawiając im własny program, przy czym w przypadku M. Kidawy-Błońskiej takich postów w ciągu miesiąca opublikowano sześć, w przypadku M. Morawieckiego zaś tylko jeden.

\section{Profesjonalizacja komunikowania kandydatów na Facebooku}

Tabela 4. Zestawienie wykorzystania funkcjonalności serwisu w prowadzonej komunikacji

\begin{tabular}{|l|l|l|}
\hline Funkcjonalności Facebooka & Małgorzata Kidawa-Błońska & Mateusz Morawiecki \\
\hline $\begin{array}{l}\text { Wyrażanie emocji - używanie } \\
\text { opisów z Facebooka }\end{array}$ & Brak & $\begin{array}{l}\text { Używano następujących } \\
\text { opisów emocji: „pełen energii”, } \\
\text { "wdzięczny”, ,podekscytowany”, } \\
\text { "pod wrażeniem”, „rozbawiony”, } \\
\text { "zachwycony”, ,zmotywowany” }\end{array}$ \\
\hline
\end{tabular}




\begin{tabular}{|c|c|c|}
\hline Sposób wyrażania emocji & 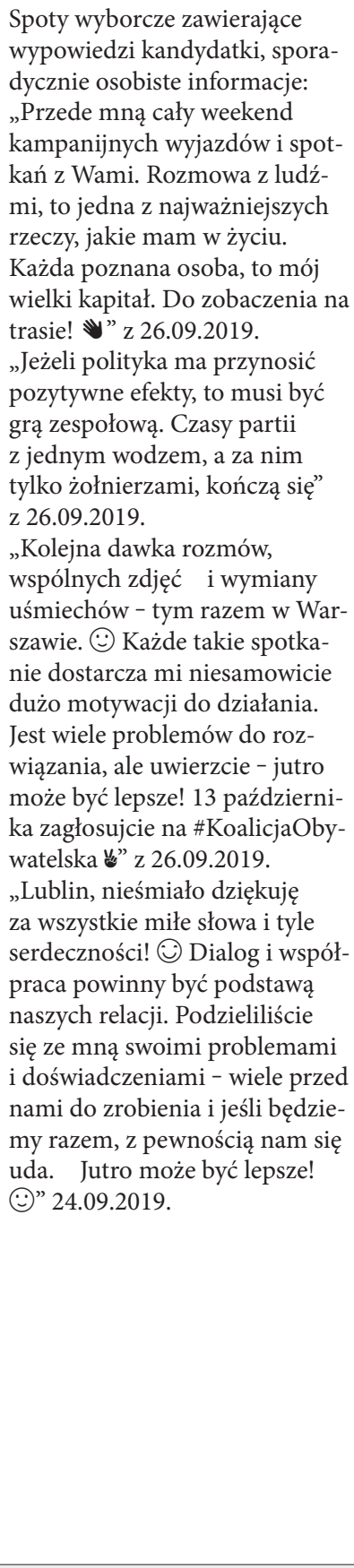 & $\begin{array}{l}\text { Osobiste formy zwracania się } \\
\text { do wyborców, osobiste zdjęcia } \\
\text { ze spotkań i wydarzeń: } \\
\text { „Gdy zakładałem ten profil } \\
\text { miesiąc temu, nie spodziewałem } \\
\text { się takiego odzewu internetowej } \\
\text { społeczności. } \\
\text { Czuję się onieśmielony i nie } \\
\text { jestem w stanie wyrazić mojej } \\
\text { wdzięczności za wszystkie cie- } \\
\text { płe słowa, które od tego czasu } \\
\text { od Państwa otrzymałem, więc } \\
\text { napiszę po prostu - dziękuję, że } \\
\text { tu jesteściepL!” z 25.09.2019. } \\
\text { „Tak to jest, jak się ma w zespole } \\
\text { wielu młodych ludzi. Świetnie } \\
\text { pracują, wszystkiego dopilnują... } \\
\text { Ale żarty i żarciki trzymają się } \\
\text { ich nieustannie. Dzisiaj padło } \\
\text { na mnie. Nazwałem je MMoji. } \\
\text { Jest wspaniałe. Dziękuję! } \\
\text { \#MMoji z 24.09.2019. } \\
\text { „Z całego serca dziękuję } \\
\text { wszystkie życzenia imienino- } \\
\text { we, które dzisiaj otrzymałem. } \\
\text { Zarówno te składane osobiście } \\
\text { na spotkaniach w Katowicach, } \\
\text { Rudzie Śląskiej, Mysłowicach } \\
\text { i Bieruniu, jak i liczne życzenia } \\
\text { SMS-owe i składane tutaj, } \\
\text { w komentarzach na Facebooku. } \\
\text { Jeszcze nigdy nie było ich tak } \\
\text { wiele. } \\
\text { W kampanii naprawdę nie- } \\
\text { trudno zapomnieć o własnych } \\
\text { imieninach. Na szczęście } \\
\text { w trasie \#JedziemyDalej udało } \\
\text { mi się kupić ciastka dla moich } \\
\text { współpracowników w piekarni } \\
\text { Państwa „Król”, u których } \\
\text { mieliśmy zaplanowany postój. } \\
\text { Dobrej nocy!” 22.09.2019. } \\
\text { „Ten moment, gdy spotykaszz } \\
\text { policjanta, a na Jego mundurze } \\
\text { zauważasz naszywkę } \\
\text { „M. Morawiecki”. } \\
\text { Panie Michale, bardzo dziękuję } \\
\text { za miłe spotkanie :-)” } \\
\text { \#MorawieckichDwoch \#Manda- } \\
\text { tuNieBylo }\end{array}$ \\
\hline Emotikony & Tak & Tak \\
\hline Hasztagi & $\begin{array}{l}\text { \#silnirazem; \#koalicjaobywatel- } \\
\text { ska; \#wybory } 2019\end{array}$ & $\begin{array}{l}\text { \#jedziemydalej; \#dobryczasPL; } \\
\text { \#dobryczasdlaPolski }\end{array}$ \\
\hline
\end{tabular}




\begin{tabular}{|l|l|l|}
\hline $\begin{array}{l}\text { Oznaczanie odwiedzanych } \\
\text { miejsc }\end{array}$ & $\begin{array}{l}\text { Tak (oznaczano miejsca spotkań } \\
\text { z wyborcami oraz miejscowo- } \\
\text { ści) }\end{array}$ & $\begin{array}{l}\text { Tak (oznaczano miejsca spotkań } \\
\text { z wyborcami oraz miejscowo- } \\
\text { ści) }\end{array}$ \\
\hline Podcasty & $\begin{array}{l}\text { Tak (nagrywane w autobusie, } \\
\text { którym podróżowała kandy- } \\
\text { datka) }\end{array}$ & Brak \\
\hline $\begin{array}{l}\text { Przekaz treści wskazujących na } \\
\text { dystans i poczucie humoru }\end{array}$ & Brak & $\begin{array}{l}\text { Udostępnienie memów i emoti- } \\
\text { konów z własnym wizerunkiem, } \\
\text { posty żartobliwie komentujące } \\
\text { nazwisko }\end{array}$ \\
\hline
\end{tabular}

Źródło: opracowanie własne na podstawie danych z serwisu Facebook.

Jak wynika z tabeli 4, kandydaci wykorzystywali funkcjonalności udostępnione przez Facebook w różny sposób. Komunikowanie prowadzone przez Kidawę-Błońską było formalne, podkreślano polityczny i partyjny charakter konta kandydatki - służyły temu hasztagi; emocje wyrażano za pomocą materiałów wyborczych. Nie ujawniono poczucia humoru kandydatki, nie wykorzystano także przekazów o charakterze emocjonalnym, które miałyby charakter osobisty; przekazy dotyczące rodziny, najbliższych, przyjaciół czy ważnych dla kandydatki wartości przekazano w formie spotów wyborczych. Morawiecki używając konta na Facebooku zbudował przekaz mniej formalny, zawartością fanpage’u podkreślał, iż jest zdystansowany wobec siebie, ma poczucie humoru i potrafi żartobliwie komentować rzeczywistość. Używane stale hasztagi nie miały tak wyraźnego wymiaru politycznego jak u kontrkandydatki. Częściej także dodawano posty bardziej osobiste, wyrażane bezpośrednio i dosłownie. W przypadku obu kandydatów interakcje z użytkownikami były sporadyczne i miały charakter czysto formalny. Nie brali oni udziału w dyskusji, w przypadku konfrontacji poglądów funkcję rozmówców pełnili inni użytkownicy, zwolennicy danego kandydata. Tym samym zbudowane wokół każdej z osób społeczności miały charakter plemienny, wykorzystywano istniejące podziały polityczne, które polaryzowały prowadzone sieciowo dyskursy wokół treści publikowanych przez kandydatów; oni sami zaś w takich dyskursach nie brali udziału.

Każdy z kandydatów korzystał z tej funkcjonalności Facebooka, która pozwala na oznaczanie miejsc (zarówno w przypadku miejscowości, jak i miejsca wydarzenia z ich udziałem). Wykres 1 ilustruje, gdzie kandydaci spotykali się z wyborcami, czyli jakie typy miejscowości odwiedzali, co pozwala na określenie środowiska realizacji kampanii wyborczej w kontekście zainteresowania określonymi grupami wyborców. 


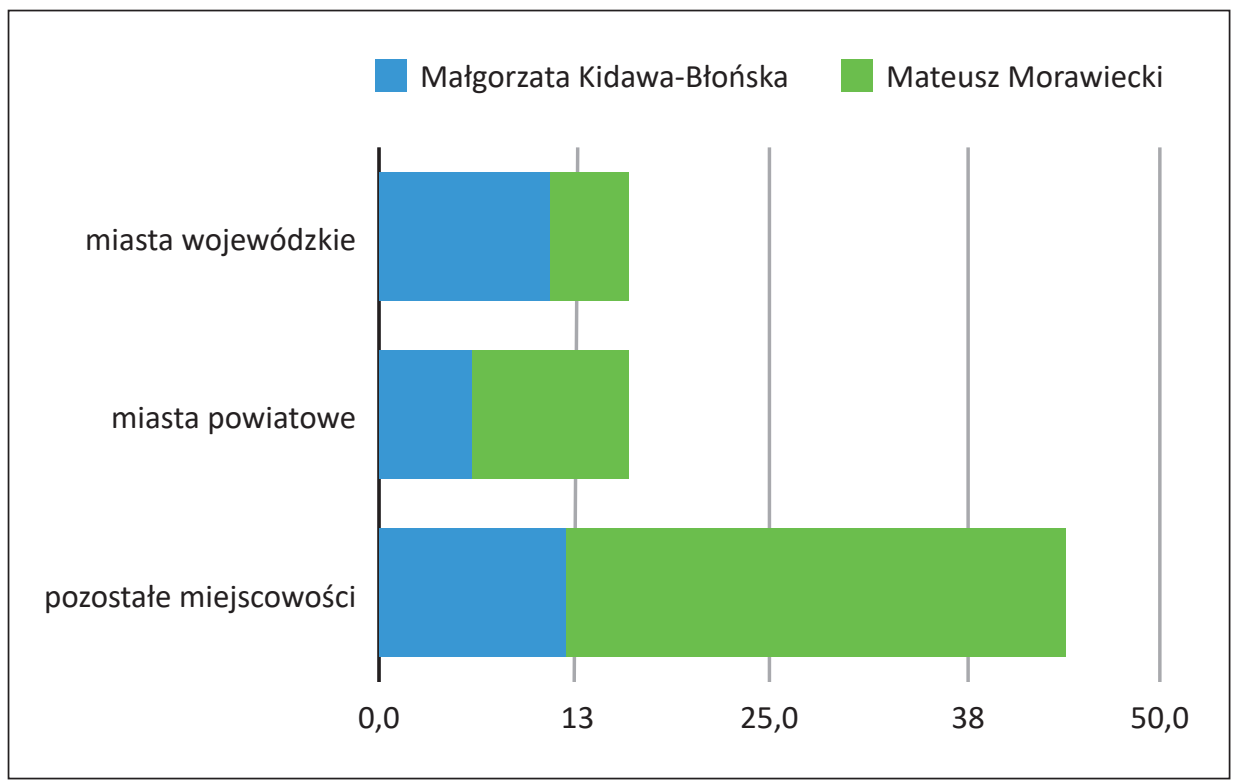

Wykres 1. Miejsca realizacji kampanii wyborczej

Źródło: opracowanie własne.

Wykres 1 obrazuje, że odwiedzane przez liderów obu partii miejscowości były odzwierciedleniem zlokalizowania popierających ich wyborców. Morawiecki częściej odwiedzał miasta powiatowe i mniejsze miejscowości, Kidawa-Błońska swoje spotkania wyborcze odbywała w miastach wojewódzkich. Oznacza to, że prowadząc kampanię nie tylko jako kandydaci, ale także jako liderzy wyborczy reprezentowanych ugrupowań politycznych ani Morawiecki, ani Kidawa-Błońska nie kierowali swojej aktywności do tych grup wyborczych, w których ze względu na wielkość miejscowości dominowali wyborcy kontrkandydata, co wskazywałoby na podejmowanie prób przełamania polaryzacji politycznej.

\section{Podsumowanie}

W przypadku obojga kandydatów większość opublikowanych postów ilustrowała ich działania prowadzone lokalnie (spotkania z wyborcami). Oznaczanie odwiedzanych miejsc z uwzględnieniem ich wielkości odpowiadało wyborcom reprezentowanych partii politycznych. Dychotomiczny podział: miasto-wieś, który został udowodniony wynikami wyborów, potwierdził, iż w dużych miastach zwyciężyła 
KO, a w mniejszych miejscowościach PiS, co jednocześnie pokrywa się z zaangażowaniem wyborczym kandydatów.

Sposób traktowania profilu w serwisie Facebook przez każdego z liderów świadczy o tym, że żaden z nich nie miał pomysłu na tworzenie samodzielnej i alternatywnej treści. Serwis ten wykorzystano zatem jako narzędzie relacjonowania prowadzonej kampanii, wzmacnianej przekazami identyfikowanymi partyjnie, co dodatkowo wpływało na proces polaryzacji politycznej. Może to świadczyć o braku pomysłu na sposób komunikacji w sieci oraz potwierdza obawy kandydatów przed zmierzeniem się z oczekiwaniami komunikacyjnymi wyborców. Za wyjątek można uznać wideocasty publikowane przez M. Kidawę-Błońską, a także treści bardziej osobiste lub wskazujące na poczucie humoru kandydata, udostępniane przez M. Morawieckiego. Zarówno opublikowane treści, jak i brak zaangażowania w powstające pod postami dyskursy potwierdzają hipotezę, iż komunikacja prowadzona przez każdego z kandydatów wzmacniała polaryzację polityczną użytkowników, którzy w przypadku udziału w dyskursie podmiotu prezentującego odmienne poglądy, identyfikowali i wzmacniali własną tożsamość polityczną. Tym samym dyskurs nie zmierzał do argumentowania, wyjaśniania czy przybliżania innych poglądów, koncentrował się natomiast na zarzutach oraz ocenie programu politycznego i postaw polityków ugrupowania konkurencyjnego. Brak udziału kandydatów w dyskursie potwierdzał, iż traktowali swoje profile jako tablice informacyjne. W przypadku M. Kidawy-Błońskiej komunikacja miała charakter formalny, była wyraźnie zorientowana politycznie i na potrzeby kampanii wyborczej; kandydatka pozycjonowała się zaś jako lider, którego celem jest przekonanie wyborców o posiadanych zdolnościach do objęcia urzędu Prezesa Rady Ministrów. Zarówno zdjęcia, jak i wypowiedzi kandydatki KO na premiera, odwoływały się do idei współpracy, podkreślały jej empatię oraz były bardziej skoncentrowane na komunikacji interpersonalnej (prezentacja na zdjęciach kandydatki podczas indywidualnych rozmów z wyborcami) niż wystąpieniach publicznych. W przypadku M. Morawieckiego komunikacja była bardziej nieformalna, jej celem było potwierdzenie zdolności przywódczych kandydata na premiera z jednoczesnym wskazaniem jego umiejętności budowania relacji z ludźmi oraz zdystansowania i poczucia humoru. Jednocześnie dzięki łączeniu funkcji urzędującego Prezesa Rady Ministrów oraz ubieganiu się o mandat poselski zakres przekazywanych informacji w przypadku M. Morawieckiego był szerszy, obejmował bowiem także informacje dotyczące wypełniania funkcji premiera. Różnice płci były czynnikiem, który różnicował obu kandydatów ze względu na sposób prowadzenia kampanii i formy komunikowania się z otoczeniem. Dokumentacja fotograficzna prezentująca aktywność M. Kidawy-Błońskiej przedstawiała kandydatkę jako członka lub lidera zespołu, co akcentowało jej umiejętność nawiązywania interakcji z wyborcami.

Z kolei M. Morawiecki był prezentowany jako lider, który potrafi przewodzić podczas publicznych wystąpień, ma do siebie dystans i przejawia poczucie humoru, co ułatwia mu nawiązywanie relacji z innymi. Kandydaci unikali treści osobistych, 
nie wykorzystali swoich profili do prezentacji informacji o charakterze prywatnym, które pozwoliłyby użytkownikom poznać mniej formalny wizerunek kandydata.

Można zatem potwierdzić hipotezę, iż profile obojga kandydatów były w badanym okresie 12.09.2019-11.10.2019 prowadzone profesjonalnie, choć był to profesjonalizm pozorny. Wykorzystywano funkcjonalności serwisu Facebook, ale jednocześnie formułowano za ich pośrednictwem treści, które nie były szczególnie interesujące ani angażujące dla użytkowników. Tak prowadzona komunikacja nie miała charakteru dialogowego, co wynikałoby z modelu komunikowania oddolnego (bottom-up), który charakteryzuje sieciową komunikację polityczną. Profile w serwisie Facebook były traktowane wyłącznie jako miejsce publikowania informacji, a nie generowania interakcji z użytkownikami. Tym samym odnosząc się do wniosków z badań prowadzonych wcześniej (zob. Olczyk, 2015, s. 83), można stwierdzić, że liderzy polityczni w Polsce nadal traktują nowe narzędzia komunikowania w tradycyjny sposób, nie wykorzystując profesjonalnie ich możliwości. Rośnie co prawda poziom wykorzystania użytkowości serwisu Facebook, co jednak nie przekłada się na wzrost dialogowego komunikowania kandydatów ani też nie wpływa na wzbogacenie treści, jakie przekazują.

Reasumując powyższe rozważania i uwzględniając w analizie uzyskane wyniki wyborcze, można wysnuć dwa wnioski. Po pierwsze, M. Kidawa-Błońska generowała większe zasięgi sieciowe $\mathrm{w}$ serwisie Facebook $\mathrm{w}$ badanym okresie 12.09.2019-11.10.2019 niż M. Morawiecki, ten z kolei zanotował niemal 100-procentowy przyrost liczby fanów. M. Kidawa-Błońska uzyskała rekordowe poparcie w Warszawie - 416 tys. głosów, a KO, którą reprezentowała, w wyborach uzyskała wynik na poziomie 27,4\% głosów. M. Morawiecki ubiegając się o mandat poselski w okręgu wyborczym obejmującym między innymi Katowice, uzyskał poparcie na poziomie 78,5 tys. głosów, Prawo i Sprawiedliwość zaś w wyborach zdobyło $43,6 \%$ głosów.

Oznacza to zatem, że wizerunek lidera generowany poprzez komunikację w serwisie Facebook nie ma tak dużego znaczenia dla wyników wyborów osiąganych przez ugrupowanie polityczne danego kandydata, ale może pośrednio oddziaływać na wizerunek ugrupowania. Drugi wniosek, który płynie z analizy, potwierdza, iż komunikacja sieciowa obu kandydatów była prowadzona bez pomysłu i nie wnosiła nic nowego do wiedzy o polityce, programach wyborczych czy samym kandydacie - nie pełniła więc ani funkcji poznawczej, ani edukacyjnej. Komunikacja obojga kandydatów w serwisie Facebook koncentrowała się głównie na banalnych treściach mobilizujących w sieci użytkowników-wyborców podzielających poglądy kandydatów.

Jak widać, przeprowadzone badania potwierdziły przyjęte w metodologii hipotezy. Komunikacja kandydatki reprezentującej Koalicję Obywatelską koncentrowała się na prezentowaniu jej jako polityka cechującego się empatią i mającego umiejętność nawiązywania bezpośrednich relacji z wyborcami, co potwierdziło ustalenia badawcze Deborah L. Rhodes i Barbary Kellerman (2007, s. 16-17) dotyczące roli 
płci. Kandydaci wykorzystywali też dostępne funkcjonalności, budując przekazy skierowane do spolaryzowanej grupy użytkowników. Ich profile w serwisie Facebook w badanym okresie nie miały spersonalizowanego charakteru, stanowiły natomiast źródło replikacji przekazów politycznych reprezentowanego przez kandydata ugrupowania wyłącznie wśród sympatyków politycznych.

\section{Bibliografia}

Anderson A.A., Brossard D., Scheufele D.S., Xenos M.A. Ladwig P. (2014). The "Nasty Effect": Online Incivility and Risk Perceptions of Emerging Technologies. „Journal of Computer-Mediated Communication", 19(3), s. 373-387.

Bessant J. (2014). Democracy Bytes: New Media, New Politics and Generational Change. London-New York: Palgrave Macmillan.

Campus D. (2010). Women Political Leaders and the Media. New York: Palgrave Macmillan.

Collins J., Singh V. (2006). Exploring Gender Leadership [w:] D. McTavish, K. Miller (eds.), Women in Leadership and Management. Cheltenham: Edward Elgar Publishing.

Davis A. (2004). Mastering Public Relations. New York: Palgrave Macmillan.

Digital 2020. (2020), https://hootsuite.com/resources/digital-2020 (dostęp: 31.12.2020).

Dijk J. van (2010). Społeczne aspekty nowych mediów. Analiza społeczeństwa sieci. Warszawa: Wydawnictwo Naukowe PWN.

El-Nawawy M., Khamis S. (2012). Political Activism 2.0: Comparing the Role of Social Media in Egypt's Facebook Revolution: and Iran's “Twitter Uprising”. „CyberOrient”, 6(1), s. 8-33.

Erisen C. (2018). Political Behavior and the Emotional Citizen. New York: Palgrave Macmillan.

Giansante G. (2015). Online Political Communication: How to Use the Web to Build the Consensus and Boost Participation. Basel: Springer International Publishing.

Grofman B., Trechsel A.H., Franklin M. (2014). The Internet and Democracy in Global Perspective: Voters, Candidates, Parties, and Social Movements. Cham-Heidelberg-New YorkDordrecht-London: Springer International Publishing.

Iyengar S., McGrady J. (2007). Media Politics: A Citizen's Guide. New York: W.W. Norton \& Company.

Iyengar S., Sood G., Lelkes Y. (2012). Affect Not Ideology: A Social Identity Perspective on Polarisation. „Public Opinion Quarterly”, 76(3), s. 1-27.

Iyengar S., Westwood S.J. (2015). Fear and Loathing across Party Line: New Evidence of Group Polarization. „American Journal of Political Sciences”, 3, s. 690-707.

Jenkins H. (2007). Kultura konwergencji. Zderzenie starych i nowych mediów. Warszawa: Wydawnictwa Akademickie i Profesjonalne.

Keohane N. (2010). Thinking about Leadership. Princeton: Princeton University Press.

Kiyohara S., Maeshima K., Owen D. (2018). Internet Election Campaigns in the United States, Japan, South Korea, and Taiwan. New York: Palgrave Macmillan.

Mason L. (2018). Ideologues without Issues: The Polarizing Consequences of Ideological Identities. „Public Opinion Quarterly”, 82(1), s. 866-887.

Mutz D.C. (2010). Psychologia polityczna a wybór [w:] R.J. Dalton, H.-K. Klingerman (red.), Zachowania polityczne, t. 1. Warszawa: Wydawnictwo Naukowe PWN.

Neely A. (2016). Donald Trump Social Media Trending Replaces Ad Spending, https://www. dmnews.com/marketing-channels/social/article/13035504/donald-trump-social-media-trending-replaces-ad-spending (dostęp: 31.12.2020). 
Olczyk T. (2014). Serwis społecznościowy jako narzędzie kampanii wyborczej - profile Bronisława Komorowskiego, Baracka Obamy i Mitta Romneya na Facebooku. „Studia Medioznawcze", 4(59), s. 87-101.

Olczyk T. (2015). Facebook w kampanii prezydenckiej w 2015 roku - analiza zawartości profili Andrzeja Dudy i Bronisława Komorowskiego. „e-Politikon”, XVI, s. 57-85.

Porębski L., Żurek M. (2017). Serwisy społecznościowe, jako narzędzie komunikowania wyborczego. Kandydaci w wyborach parlamentarnych w roku 2015 na Facebooku. „Athenaeum. Polskie Studia Politologiczne", 53, s. 154-168.

Rhodes D., Kellerman B. (2007). Women and Leadership the State of Play [w:] D. Rhode, B. Kellerman (eds.), Women and Leadership. San Francisco: Wiley and Sons.

Schulz W. (2014). Mediatization and New Media [w:] F. Esser, J. Strömbäck (eds.), Mediatization of Politics Understanding the Transformation of Western Democracies. New York: Palgrave Macmillan.

Semetko A.H. (2010). Komunikacja polityczna [w:] R.J. Dalton, H.-K. Klingerman (red.), Zachowania polityczne, t. 1. Warszawa: Wydawnictwo Naukowe PWN.

Shehata A., Strömbäck J. (2014). Mediation of Political Realities: Media as Crucial Sources of Information [w:] F. Esser, J. Strömbäck (eds.), Mediatization of Politics Understanding the Transformation of Western Democracies. New York: Palgrave Macmillan.

Sheingate A. (2016). Building a Business of Politics: The Rise of Political Consulting and the Transformation of American Democracy. New York: Oxford University Press.

Smith A. (2014). Cell Phones, Social Media, and Campaign, 2014, https://www.pewresearch.org/ internet/2014/11/03/cell-phones-social-media-and-campaign-2014/ (dostęp: 31.12.2020).

Sun W. (2018). A Critical Discourse Analysis of "Minority Women for Trump" Campaigns on Social Media [w:] N. Bilge, M.I. Marino (eds.), Reconceptualizing New Media and Intercultural Communication in a Networked Society. Hershey: IGI Global.

Umbach M., Humphrey M. (2018). Authenticity: The Cultural History of a Political Concept. Cham: Palgrave Macmillan. 
